\title{
Preparation of Hulu-mur flavored carbonated beverage based on Feterita sorghum (Sorghum bicolor) malt
}

\author{
Sara F. A. Baidab ${ }^{a}$, Solafa A. Hamad ${ }^{a}$, Abdel Halim R. Ahmed ${ }^{b}$, And Isam A. \\ Mohamed Ahmed ${ }^{\mathrm{c}^{*}}$ \\ ${ }^{\text {a }}$ Food Research Center, Khartoum North, P.O. Box 213, Shambat, Sudan \\ b School of Health Sciences, Ahfad University for Women, Omdurman, Sudan \\ ${ }^{\mathrm{c}}$ Department of Food Science and Technology, Faculty of Agriculture, University of Khartoum, Shambat \\ 13314, Sudan \\ * Corresponding author \\ isamnawa@yahoo.com
}

Received: 7 May 2015; Published online: 18 October 2016

\begin{abstract}
In this study, sorghum Feterita malt extract was used to prepare carbonated beverages flavored with traditional Hulu-mur spices extract. The beverages produced were assessed for their physicochemical, sensory, and nutritional qualities. Malting (3-5 days) of the Feterita grains showed significant $(P \leq$ $0.05)$ differences in proximate composition from that of unmalted grains. Protein and sugars increased significantly $(P \leq 0.05)$ with increased the malting time (days), while there was a significant $(P \leq 0.05)$ reduction in oil and starch content during malting progress. The kilning temperature of $150{ }^{\circ} \mathrm{C}$ for 20 minutes was found to produce the most acceptable Hulu-mur carbonated beverage analogue in terms of flavor and taste. Significant differences $(P \leq 0.05)$ were observed in physicochemical and nutritional qualities between the Hulu-mur analogue carbonated beverage and commercial non-alcoholic beverage. The Hulu-mur carbonated beverage analogue was rich in Na, K, Ca, and Fe $(26.45,21.84,24.00$, and $0.57 \mathrm{mg} / 100 \mathrm{~g}$, respectively) compared to levels of the same minerals in the non-alcoholic beverage $(22.31,8.19,22.00$ and $0.15 \mathrm{mg} / 100 \mathrm{~g}$, respectively). The Hulu-mur analogue also had a higher calorific value $(35.85 \mathrm{kcal} / 100 \mathrm{~mL})$ compared to the non-alcoholic beverage $(32.96 \mathrm{kcal} / 100 \mathrm{~mL})$.
\end{abstract}

Keywords: Carbonated beverage; Feterita; Germination; Hulu-mur; Sorghum

\section{Introduction}

Carbonated beverages are very popular and are consumed by people of all ages for different reasons such as taste, refreshment, relaxation, pleasure, sociability and commonly to quench thirst (El-Faki \& Eisa, 2008). Carbonated drinks are appropriate at any time of day, with or without any claim of nutritional value. These beverages are generally made with water plus $1-3 \%$ liquid carbon dioxide, 3-5\% liquid sugars, acidified to a $\mathrm{pH}$ of about 3.5 , emulsifiers, colors, flavors and /or spices, herbs and extracts of roots leaves seeds, flowers or bark may be added (El-Faki \& Eisa, 2010). Although claims for the medicinal properties of these carbonated beverages have been overstated, the presence of carbon dioxide does make these drinks more pleasant and visually attractive (Steen, 2007). Globally, mass production of carbonated beverages is huge and according to the Coca-cola Company fact sheet, they alone have sales that exceed 1.7 billion servings per day. Considering the fact that it is not the only bottler worldwide, clearly the volume of carbonated beverages produced each day is massive (Dwidar, Lee, \& Mitchell, 2012). In the Su- 
dan, the annual production of carbonated beverages was estimated to be 45 million in the 2004 (EL-Mubarak, Abdalgadir, \& Mohamed, 2005) and is still growing every year due to the great demand for these drinks. However, studies on the development of carbonated drinks from sorghumbased malt with traditional flavor have not been investigated.

Sorghum (Sorghum bicolor L. Moench), together with Millet, are the main cereal crops in the semiarid tropics and are commonly consumed by the poorer population in many countries in Africa and Asia where they form major sources of proteins and calories in the diet of large segments of the population in these areas (Belton \& Taylor, 2004). Sorghum is the indigenous crop in the Sudan and is the major and staple food grain, as well as being fodder for livestock (Elkhalifa \& Bernhardt, 2013). It is generally consumed as fermented flat bread (Kisra), thick porridge (Aceda), thin fermented gruel (Nasha), nonalcoholic beverages (Abreh and Hulu-mur) and alcoholic beverages such as Merissa and Assaliya (Elbaloula, Yang, Guo, \& Gu, 2014; Elkhalifa \& Bernhardt, 2013). Feterita is the main sorghum cultivar that is preferably used for the preparation of traditional beverages in the Sudan (Dirar, 1993) due to its high content of starch and sugars. Hulu-mur is a great traditional Sudanese non-alcoholic beverage prepared from spices flavored fermented dough (1:1) of unmalted and malt sorghum flour and consumed by large a portion of the people as a refreshing drink to quench the thirst of the fasting of Ramadan (Agab, 1985; Ibnouf, 2012). The fermented dough is baked into thin brown sheets and then broken down to smaller flakes, which could be stored for more than two years at room temperature (Ibnouf, 2012). To prepare the drink, the flakes are soaked in water and the dark reddish-brown supernatant is decanted and then sweetened with sugar before serving (Agab, 1985). This unique refreshing drink has both sweet and sour taste in addition to a unique flavor that comes from extracts of different spices and condiments such as ginger (Zingiber officinate), cinnamon (Cinnamonium zeylanicum), galangal (Alpinia officinarum), coriander (Coriandrum sativum), cardamom (Elettaria cardamomum), black pepper (Piper nigrum), cumin (Cuminum cyminum), hibiscus
(Hibiscus sabdriffa), tamarind (Tamarindus indica), and dates (Phoenix dactylifera). In addition, this drink may have good nutritional and health promoting qualities developed by the germination and fermentation processes of sorghum grains and the added spices. Due to that, Hulumur has great desirability and popularity as a non-alcoholic soft drink at both national and regional levels. Though the processes of Hulu-mur preparation are laborious it is still commonly made domestically, a fact that makes large-scale production and marketing of this incredible drink potentially difficult to establish. There is a need to improve and standardize the preparation of Hulu-mur to facilitate the development of a modernized and industrialized method of manufacture of hulu-mur. The main aim of this study was therefore to develop a non-alcoholic carbonated beverage from sorghum malt extract flavored with hulu-mur flavors and to evaluate the nutritional and sensory qualities of the developed beverage.

\section{Materials and Methods}

\section{$2.1 \quad$ Materials}

The grains of local sorghum variety Feterita and citric acid were obtained from the Food Research Center, Khartoum, Sudan. The spices (tamarind, ginger, fenugreek, black cumin seed, galangal, and cinnamon) and sugar were purchased from a local market, Khartoum, Sudan. The $\mathrm{CO}_{2}$ in liquid form (soda water) was obtained from the Coca-Cola Company, Khartoum, Sudan. Chemical reagents used in this study were all of analytical grade.

\subsection{Germination (malting) of sorghum grain}

Sorghum grains were cleaned and soaked in water overnight. The grains were then spread on trays and covered with wetted cloth and kept wet by frequent spraying with water. After 3 and 5 days, the germinated grains were harvested and left to dry under sunlight. Germinated grains were then screened for malting characteristics and the 
grains with good malting performance were used for the preparation of the carbonated beverage.

\subsection{Kilning of sorghum malt}

Malted grains of Feterita variety with best malting characteristics were cleaned from roots and shoots and kilned in an oven at different temperatures $\left(100,150\right.$ and $200{ }^{\circ} \mathrm{C}$ ) for different times (10, 20, 30 and 60 min) (Lasekan, Lasekan, \& Idowu, 1997), to select appropriate kilning conditions to be used throughout this study.

\subsection{Preparation of Hulu-mur flavors}

The main herbs and spices used traditionally in preparation of Sudanese Hulu-mur flavors (e.g. Tamarind, cinnamon, ginger, galangal, black pepper, cumin, coriander, dates, and hibiscus) were mixed in different traditionally recommended portions for presumptive testing to produce a suitable mix for the extraction of the most acceptable flavor. After few trial batches, a blend of the herbs was found to be most suited when equal portions of each herb were mixed and taken as the mix for extraction of flavors. Then, a Hulu-mur flavor was prepared by extraction of $60 \mathrm{~g}$ of the herbs mix and condiments in $500 \mathrm{~mL}$ water followed by boiling for $30 \mathrm{~min}$. The extract was filtered through a filter cloth, and centrifuged at $3000 \times \mathrm{g}$ to obtain a clear supernatant of about $1 \%$ total soluble solids.

\subsection{Preparation of sorghum malt extract}

Feterita malt that had been kilned for the most suitable temperatures and times $\left(150{ }^{\circ} \mathrm{C}\right.$ for 20 min or $200{ }^{\circ} \mathrm{C}$ for $20 \mathrm{~min}$ ) was used in preparation of sorghum malt extract. About $1.0 \mathrm{~kg}$ malted grains was extracted with $8 \mathrm{~L}$ of water containing $70 \mathrm{~g}$ hops. The mixture was left to boil for 60 min before filtration using a filter cloth to yield an extract of $3.0 \%$ T.S.S. The malt base was prepared first by adding the Hulu-mur flavor extract to sorghum malt extract at a ratio of $1: 2.5$
(Hulu-mur flavor: malt extract) and $3.5 \mathrm{~g}$ citric acid. The total soluble solids were raised to $50 \%$ using sucrose powder. The malt base was kept in the refrigerator $\left(4{ }^{\circ} \mathrm{C}\right)$ to cool. Polyethylene tetraphalate $(\mathrm{PET})$ bottles $(350 \mathrm{ml})$ were washed aseptically, and then $250 \mathrm{ml}$ of the malt base was poured into the bottle first and topped up with $100 \mathrm{ml}$ of cold soda water (Courtesy of DAL Group). The bottle was then closed tightly and kept in the refrigerator $\left(6{ }^{\circ} \mathrm{C}\right)$ until used for the analysis of physicochemical, nutritional, and sensory qualities.

\subsection{Sensory evaluation}

Initially, the samples of carbonated beverages prepared from Feterita malt extract that were kilned for $20 \mathrm{~min}$ at temperatures of 150 and $200{ }^{\circ} \mathrm{C}$ were subjected to sensory evaluation (five points hedonic scale) using the paired comparison test to select the best one. Thereafter, triplicate samples of the developed carbonated beverage (Hulu-mur analogue) and commercially available carbonated beverages were subjected to the sensory evaluation (acceptability testing) using the 5 points hedonic scale. Fifteen semi-trained panelists from the Food Research Centre were asked to evaluate the different carbonated beverage in terms of color (appearance), flavor (odour and taste), taste (mouth feel), and overall acceptability. The scoring method was conducted to compare different perceptions, and then the sensory rating results were statistically analyzed.

\subsection{Proximate analysis}

The moisture (950.46B), ash (920.153), fiber (962.09), lipids (960.39), crude protein (981.10), and carbohydrate content of the feterita seed samples $(\mathrm{n}=3)$ were determined following the official methods of analysis (AOAC, 2003). Carbohydrate content was determined by subtracting the content of moisture, protein, ash, fiber and fat from 100. The entire results of the chemical analyses were calculated on dry weight basis. 


\subsection{Physiochemical properties of Hulu-mur analogue and commercial beverage}

The total and reducing sugars were determined by titration methods with Fehling solutions as described in the official standard method (AOAC, 2000). The total soluble solids (TSS) were determined using a hand refractometer according to the standard method (AOAC, 2000) method. The $\mathrm{pH}$ of the Hulu-mur analogue and commercial non-alcoholic beverages was measured using a pH Meter (Hanna, Model HI 8521) at ambient temperature. The titratable acidity (TA) was determined according to the method described by Ranganna (2001) and expressed as a percentage of citric acid. The optical density of the brown color (non-enzymatic browning) of the carbonated beverages was determined spectrophotometrically at $490 \mathrm{~nm}$ (Askar \& Treptow, 1993). The caloric values were calculated based on the values obtained by multiplying the contents of fats, protein and carbohydrate by coefficients of $8.37,3.89$, and $4.12 \mathrm{kcal} / \mathrm{g}$, respectively (IMNA, 2002).

\subsection{Minerals content}

Minerals content were determined by the dry ashing method(Chapman \& Pratt, 1982). Calcium (Ca) and magnesium (Mg) were measured by titration. Potassium and sodium were determined by using a flame photometer (Corning 400, Holstead, Essex, UK) according to the official method (AOAC, 2000). Iron was determined by atomic absorption spectrophotometer (Shimadzu AA-680, Shimadzu, Japan).

\section{$2.10 \quad$ Statistical analysis}

Three separate batches, of each particular process, were taken and analyzed separately, and the results were then averaged. The data obtained were subjected to analysis of variance (ANOVA) and the significance of differences among the means was determined by the Duncan Multiple Range Test (DMRT) at $P \leq 0.05$ significance level (Mead \& Curnow, 1983).

\section{Results and Discussion}

\subsection{Effect of malting on chemical composition of the grains of Feterita cultivar}

Table 1 shows the changes in chemical composition of malted grains of Feterita cultivar. Results showed that Feterita cultivar had 10.03\% protein, $3.48 \%$ fat, $1.73 \%$ ash, and $2.35 \%$ fiber. With exception of protein, the results are comparable with those reported previously for other sorghum cultivars (Nour, Ahmed, Babiker, \& Yagoub, 2010). The variation in protein content could be attributed to the differences in genetic makeup, environmental condition, and agronomical practices (Nour et al., 2010). Malting (3-5 days) of the grains resulted in significant $(P \leq 0.05)$ differences in nutrients levels when compared to that of unmalted grains. Protein and sugars increased significantly $(P \leq 0.05)$ with increased malting time (days) while oil and starch showed a significant $(P \leq 0.05)$ reduction during malting progress. The reduction of starch and oil could be due to the hydrolysis of these components, respectively, to monosaccharide and fatty acids by hydrolytic enzymes, which were used as an energy source during grain germination and embryo growth (Elbaloula et al., 2014). Ash content significantly decreased ( $P \leq$ $0.05)$ at 3 days malting, whereas, there was no significant $(P \geq 0.05)$ increase at 5 days malting. Fiber content showed a significant $(P \leq$ $0.05)$ increase at 3 days, however, it was significantly $(P \leq 0.05)$ reduced at 5 days of malting. Similar changes in the values of nutrient composition were observed during malting of various cereal grains (Chaudhary \& Vyas, 2014; Elbaloula et al., 2014; Kim, Kim, Kang, \& Lee, 1993; Nour et al., 2010; Traore, Mouquet, IcardVerniere, Traore, \& Treche, 2004). The changes in the nutrients contents could be attributed to the leaching of soluble components into soaking water prior to malting and to the action of various hydrolytic enzymes during malting process (Elbaloula et al., 2014; Elmaki, Babiker, \& El Tinay, 1999; Nour et al., 2010). The quantitative reduction in anti-nutritional factors during malting process might also contribute to the 
Table 1: Chemical composition (dry matter basis) of raw and malted grains of Feterita sorghum cultivar

\begin{tabular}{|c|c|c|c|c|c|c|c|}
\hline \multirow{3}{*}{ Feterita grains } & \multirow{3}{*}{$\begin{array}{r}\text { Protein } \\
(\%)\end{array}$} & \multirow{3}{*}{$\begin{array}{l}\text { Ash } \\
(\%)\end{array}$} & \multirow{3}{*}{$\begin{array}{l}\text { Fat } \\
(\%)\end{array}$} & \multicolumn{4}{|c|}{ Total CHO } \\
\hline & & & & \multirow{2}{*}{$\begin{array}{r}\text { Fiber } \\
(\%)\end{array}$} & \multicolumn{2}{|c|}{ Sugar (\%) } & \multirow{2}{*}{$\begin{array}{r}\text { Strach }+ \text { others } \\
(\%)\end{array}$} \\
\hline & & & & & Total (\%) & Reducing (\%) & \\
\hline Raw & $10.03 \pm 0.13^{c}$ & $1.73 \pm 0.09^{a}$ & $3.48 \pm 0.22^{a}$ & $2.35 \pm 0.04^{b}$ & $1.55 \pm 0.04^{c}$ & $0.89 \pm 0.13^{c}$ & $79.62 \pm 1.58^{a}$ \\
\hline Malted 3 days & $10.57 \pm 0.10^{b}$ & $1.55 \pm 0.05^{b}$ & $3.15 \pm 0.05^{b}$ & $2.43 \pm 0.00^{a}$ & $3.82 \pm 0.29^{b}$ & $2.12 \pm 0.33^{b}$ & $76.12 \pm 0.18^{b}$ \\
\hline Malted 5 days & $10.93 \pm 0.17^{a}$ & $1.78 \pm 0.06^{a}$ & $3.05 \pm 0.03^{c}$ & $2.23 \pm 0.02^{c}$ & $5.87 \pm 0.41^{a}$ & $3.27 \pm 0.25^{a}$ & $72.87 \pm 2.01^{c}$ \\
\hline
\end{tabular}

changes in the nutrient composition of malted grains (Chaudhary \& Vyas, 2014; Hassan et al., 2006).

\subsection{Effect of kilning temperature and time on the physicochemical properties of Feterita malt}

Table 2 shows the results of physicochemical properties of Feterita malt kilned at temperatures of 100,150 and $200{ }^{\circ} \mathrm{C}$ for 10 to $60 \mathrm{~min}$. Total soluble solids (TSS) decreased significantly $(P$ $\leq 0.05$ ) during the rising of kilning temperature from 100 to $200{ }^{\circ} \mathrm{C}$ and time from 10 to $60 \mathrm{~min}$. It was obvious that both high kilning temperature and longer kilning time have an adverse effect on soluble compounds in sorghum malt extract. The phenomenon was said to be attributed to Maillard reaction, which renders some of the reducing sugars and free amino acids (Kim et al., 1993). Okoli, Okolo, Moneke, and Ire (2010) observed a decrease in soluble compounds in cereal malt because of the increase in kilning temperature. The optical density (color) of sorghum malt extract kilned for different temperatures (100, 150 and $200{ }^{\circ} \mathrm{C}$ ) and at different times (10 to $60 \mathrm{~min}$ ) was also significantly affected by both factors. The intensity of the color absorbed at $490 \mathrm{~nm}$ increased significantly $(P \leq 0.05)$ due to increasing of kilning temperature and prolonging malt exposure time. The intensity of the color increased from 0.273 O.D to 0.896 O.D by increasing kilning temperature and time to $200{ }^{\circ} \mathrm{C}$ and 60 min, respectively. The primary objective of malt kilning is to develop a dark color through Millard Reaction between sugars and amino acids in malted grains (Coghe, D'Hollander, Verachtert,
\& Delvaux, 2005). In contrast, Phiarais, Wijngaard, and Arendt (2005) used lower temperatures $\left(100-110{ }^{\circ} \mathrm{C}\right)$ to develop dark color in low enzyme activity malts of Buckwheat. However, in another study the malt is classified into three groups (color malts, caramel malts, and roasted malts) as affected by kilning temperature (Coghe, Martens, D'Hollander, Dirinck, \& Delvaux, 2004). In this study, we observed that extending kilning time beyond 20 minutes produced slight turbidity in the extract due to the presence of some insoluble components, which might have resulted from the reaction between polyphenols and proteins (Hosseini, Kadivar, \& Shahedi, 2012). This undesirable phenomenon necessitated selection of $20 \mathrm{~min}$ as optimum time for kilning and selection of optimum kilning temperatures of 150 and $200{ }^{\circ} \mathrm{C}$. The $\mathrm{pH}$ values of malt extract were insignificantly different $(P \geq$ 0.05) during raising kilning temperature from 100 to $200{ }^{\circ} \mathrm{C}$ and kilning time from 10 to 60 minutes(Table 2). The $\mathrm{pH}$ of Feterita extract kilned at 100,150 and $200{ }^{\circ} \mathrm{C}$ for 10 to 60 minutes was ranged from 5.23 to 5.92 , which was within the recommended $\mathrm{pH}$ range (5.3-6.0) of sorghum malt extracts (Agu \& Palmer, 1998). This result is similar to those of Ulaiwan (2008) who found that no significant difference was observed in the $\mathrm{pH}$ of malt extract of grains kilned at different temperatures (low, medium and high) and different times. 
Table 2: Effect of kilning temperature and time on the physicochemical properties of Feterita malt

\begin{tabular}{|c|c|c|c|c|c|c|c|c|c|}
\hline \multirow{2}{*}{$\begin{array}{l}\text { Kilning time } \\
(\min )\end{array}$} & \multicolumn{9}{|c|}{ Kilning Temperature (C) } \\
\hline & 100 & 150 & 200 & \multicolumn{3}{|c|}{ Color (OD $490 \mathrm{~nm})$} & 100 & 150 & 200 \\
\hline 10 & $6.00 \pm 0.46^{a}$ & $5.30 \pm 0.14^{b}$ & $4.30 \pm 0.36^{c d}$ & $0.27 \pm 0.02^{e}$ & $0.30 \pm 0.03^{c d}$ & $0.41 \pm 0.04^{c}$ & $5.56 \pm 0.43^{b}$ & $5.56 \pm 0.43^{b}$ & $5.64 \pm 0.44^{a b}$ \\
\hline 30 & $5.00 \pm 0.40^{b c}$ & $3.10 \pm 0.21^{d e}$ & $2.50 \pm 0.16^{e}$ & $0.34 \pm 0.04^{c d}$ & $0.64 \pm 0.06^{b}$ & $0.80 \pm 0.07^{a}$ & $5.67 \pm 0.47^{a b}$ & $5.60 \pm 0.46^{a b}$ & $5.23 \pm 0.33^{b c}$ \\
\hline 60 & $4.50 \pm 0.38^{c}$ & $2.40 \pm 0.15^{e}$ & $2.00 \pm 0.13^{e f}$ & $0.49 \pm 0.04^{c}$ & $0.80 \pm 0.06^{a b}$ & $0.90 \pm 0.07^{a}$ & $5.61 \pm 0.45^{a b}$ & $5.61 \pm 0.45^{a b}$ & $5.92 \pm 0.48^{a}$ \\
\hline
\end{tabular}

Values are means of triplicates $( \pm \mathrm{SD}) .^{a-f}$ Mean average within columns and rows for each parameter bearing different letters are significantly different at $(P \leq 0.05)$

Table 3: Effect of kilning temperature on the sensory quality of non-alcoholic beverage prepared from sorghum malt extract

\begin{tabular}{lllll}
\hline \multirow{2}{*}{$\begin{array}{l}\text { Sorghum malt } \\
\text { extract beverage }\end{array}$} & \multicolumn{2}{l}{ Quality attributes } & \\
\cline { 2 - 5 } & $\begin{array}{l}\text { Color } \\
\text { (appearance) }\end{array}$ & $\begin{array}{l}\text { Flavor } \\
\text { (odour + taste) }\end{array}$ & $\begin{array}{l}\text { Taste } \\
\text { (mouth feel) }\end{array}$ & $\begin{array}{l}\text { Overall } \\
\text { acceptability }\end{array}$ \\
\hline Kilning $150^{\circ} \mathrm{C}$ & $4.64 \pm 0.52^{a}$ & $3.91 \pm 0.47^{a}$ & $3.91 \pm 0.47^{a}$ & $4.09 \pm 0.56^{a}$ \\
Kilning $200^{\circ} \mathrm{C}$ & $3.36 \pm 0.41^{b}$ & $3.36 \pm 0.41^{b}$ & $3.54 \pm 0.35^{b}$ & $3.27 \pm 0.41^{b}$ \\
\hline
\end{tabular}

Values are means of triplicates $( \pm \mathrm{SD}) .{ }^{a-b}$ Mean average in the same column with different letters is significantly different at $(P \leq 0.05)$. Hedonic scale $(1-5,1=$ poor, $5=$ excellent $)$

\subsection{Sensory attributes of Feterita malt carbonated beverage (Hulu-mur analogue) and others commercial carbonated beverages}

The sensory evaluation of raw materials gives an instant indication of the overall quality of the final product (Coghe et al., 2004). To select best combinations of kilning temperature and time based on the consumer preferences, the sensory characteristics of non-alcoholic beverage prepared from sorghum malt extract kilned for 20 minutes at 150 and $200{ }^{\circ} \mathrm{C}$ were analyzed (Table 3$)$. There were significant differences $(P \leq$ 0.05 ) between the two beverages in color (appearance), flavor, taste, and overall acceptability. Interestingly, Feterita malt beverage prepared from the malt extract kilned at $150{ }^{\circ} \mathrm{C}$ for 20 minutes received higher scores for all tested quality attributes compared to those prepared from an extract of sorghum malt kilned at 200 ${ }^{\circ} \mathrm{C}$ for 20 minutes. Previous observation had indicated that roasting or kilning of barley and malt products generates color and flavor, controlled principally by the time course of product temperature (Yahya, Linforth, \& Cook, 2014). Thus, in the current study, kilning Feterita malt at $150{ }^{\circ} \mathrm{C}$ for 20 minutes was most suitable for the production of acceptable non-alcoholic beverage analogue, and consequently this combination of kilning time and temperature was used for the development of Hulu-mur analogue carbonated beverage.

To evaluate the acceptability and competiveness of hulu-mur analogue, the sensory attributes of hulu-mur analogue carbonated beverages and some commercially available carbonated beverages were analyzed (Table 4 ). The results showed significant differences $(P \leq 0.05)$ in color (appearance) among different carbonated beverages. Orange flavor received the highest scores whereas Hulu-mur analogue and lemon flavor recorded the same scores, and coca cola flavor beverage received the lowest scores. The Hulu-mur analogue beverage was judged almost similar to lemon flavor, with orange flavor given the highest scores. There was no significant difference $(P \leq 0.05)$ in taste (mouth feel) between Hulu-mur analogue beverage and lemon flavor beverage. In general, it was clear that Hulu-mur analogue prepared from sorghum malt extract was similar in overall quality to a lemon flavored beverage, which 
Table 4: Comparison of the sensory acceptability of Feterita malt carbonated beverage (Hulu-mur analogue) against some commercial carbonated beverages

\begin{tabular}{lllll}
\hline \multirow{2}{*}{$\begin{array}{l}\text { Carbonated } \\
\text { Beverage }\end{array}$} & \multicolumn{4}{l}{ Quality attributes } \\
\cline { 2 - 5 } & $\begin{array}{l}\text { Color } \\
\text { (appearance) }\end{array}$ & $\begin{array}{l}\text { Flavor } \\
\text { (odour + taste) }\end{array}$ & $\begin{array}{l}\text { Taste } \\
\text { (mouth feel) }\end{array}$ & $\begin{array}{l}\text { Overall } \\
\text { acceptability }\end{array}$ \\
\hline Apple flavor & $3.91 \pm 0.58^{a b}$ & $3.54 \pm 0.61^{a b}$ & $3.91 \pm 0.58^{a}$ & $4.09 \pm 0.61^{a}$ \\
Orange flavor & $4.09 \pm 0.61^{a}$ & $3.81 \pm 0.73^{a}$ & $3.81 \pm 0.73^{a b}$ & $3.73 \pm 0.51^{b}$ \\
Lemon flavor & $3.27 \pm 0.42^{b}$ & $2.91 \pm 0.39^{c}$ & $2.73 \pm 0.40^{c d}$ & $2.82 \pm 0.36^{d}$ \\
Cola flavor & $2.54 \pm 0.37^{c}$ & $3.36 \pm 0.45^{b}$ & $3.59 \pm 0.62^{b}$ & $3.59 \pm 0.62^{c}$ \\
Hulu-mur flavor & $3.27 \pm 0.42^{b}$ & $2.88 \pm 0.36^{c d}$ & $2.81 \pm 0.41^{c}$ & $2.82 \pm 0.36^{d}$ \\
\hline
\end{tabular}

Values are means of triplicates $( \pm \mathrm{SD}){ }^{a-d}$ Mean average in the same column with different letters are significantly different at $(P \leq 0.05)$. Hedonic scale $(1-5,1=$ poor, $5=$ excellent $)$

was already established in the market. Thus, organoleptically the hulu-mur analogue carbonated beverage could compete with other commercially available carbonated beverages.

\subsection{Physicochemical and nutritional qualities of Hulu-mur analogue and commercial non-alcoholic carbonated beverage}

The acceptability of beverages is very much dependent on their physicochemical properties that advanced the formation of flavor, aroma and nutritional value of the final product. Table 5 shows physicochemical and nutritional qualities of Hulu-mur analogue and commercial nonalcoholic carbonated beverages known as Champion (Barely flavor). The total soluble solids (TSS) of Hulu-mur analogue were significantly $(P$ $\leq 0.05$ ) higher than the value of commercial nonalcoholic beverages. These values were within the range of $10-14 \%$ reported for tamarindcarbonated beverage (Mustafa, 2007) and higher than $9.0 \%$ reported for Amla (Emblica officinalis L.) fruits non-alcoholic carbonated beverage (Jairath, Sahota, \& Pandove, 2012). The $\mathrm{pH}$ of Hulu-mur analogue (2.20) was significantly $(P \leq 0.05)$ lower than that of the commercial non-alcoholic beverages $\mathrm{pH}$ (2.97). Obuzor and Ajaezi (2010) reported that, malt drinks are quite acidic with a pH of 4.4 (Malta Guinness and Maltina) and 4.6 (Amstel, Hi-malt and Grand malt). In addition, slightly higher $\mathrm{pH}$ (2.6) was also reported for non-alcoholic carbonated beverage from amla fruits (Jairath et al., 2012). The titrable acidity of Hulu-mur analogue (0.38\%) was higher $(P \leq 0.05)$ than that of commercial non-alcoholic carbonated beverage $(0.25 \%)$. It is, however, laid within the range (0.09-2.9 \%) reported for a tamarind-carbonated beverage (Mustafa, 2007). The optical density of hulumur analogue (color) was significantly $(P \leq 0.05)$ higher than that of commercial non-alcoholic carbonated beverage.

Total and reducing sugars showed significant $(P$ $\leq 0.05)$ differences between hulu-mur analogue and commercial non-alcoholic carbonated beverage. The commercial non-alcoholic carbonated beverage contains higher $(P \leq 0.05)$ levels of total and reducing sugars compared to hulumur analogue beverage. Although the variation in total sugars was not big, the reducing sugars of commercial beverage were more than 5 times higher than that of hulu-mur analogue. This could be due to the increased activities of starch and sugar hydrolyzing enzymes during germination and fermentation processes of hulu-mur analogue, with the latter likely to be the major cause of such low content of reducing sugars in the developed beverage. Strikingly, a low sugar content of hulu-mur analogue is an advantage of the product to be consumed by wide range of people, with minor concerns of gaining weight and obesity (Malik, Schulze, \& $\mathrm{Hu}$, 2006). Soluble nitrogen of hulu-mur analogue and commercial non-alcoholic carbonated bev- 
Table 5: Comparison of physicochemical and nutritional properties of hulu-mur analogue and commercial non -alcoholic beverage (known as Champion)

\begin{tabular}{lll}
\hline Parameter & Hulu-mur analogue & $\begin{array}{l}\text { Commercial non-alcoholic } \\
\text { beverage (Champion) }\end{array}$ \\
\hline Total soluble solids (\%) & $12.00 \pm 0.23^{a}$ & $11.00 \pm 0.15^{b}$ \\
pH-value & $2.20 \pm 0.65^{b}$ & $2.97 \pm 0.12^{a}$ \\
Titrable acidity (\% citric acid) & $0.38 \pm 0.01^{a}$ & $0.25 \pm 0.00^{b}$ \\
Color (OD 490 nm) & $1.14 \pm 0.00^{a}$ & $0.51 \pm 0.01^{b}$ \\
Total sugars (\%) & $7.72 \pm 0.58^{b}$ & $8.31 \pm 0.67^{a}$ \\
Reducing sugars (\%) & $0.65 \pm 0.02^{b}$ & $3.00 \pm 0.00^{a}$ \\
Soluble Nitrogen (\%) & $0.42 \pm 0.03^{a}$ & $0.00 \pm 0.00^{b}$ \\
Calorific value (kcal/100 ml) & $35.85 \pm 8.97^{a}$ & $32.96 \pm 6.24^{b}$ \\
Na (mg/ 100 g) & $26.45 \pm 1.13^{a}$ & $22.31 \pm 0.97^{b}$ \\
K (mg/ 100 g) & $21.84 \pm 1.65^{a}$ & $8.19 \pm 0.63^{b}$ \\
Ca (mg/ 100 g) & $24.00 \pm 1.07^{a}$ & $22.00 \pm 0.95^{b}$ \\
Mg (mg/ 100 g) & $2.88 \pm 0.19^{a b}$ & $3.12 \pm 0.27^{a}$ \\
Fe (mg/ 100 g) & $0.57 \pm 0.06^{a}$ & $0.15 \pm 0.00^{b}$ \\
\hline
\end{tabular}

Values are means of triplicates $( \pm \mathrm{SD}) \cdot{ }^{a-b}$ Mean average in the same raw with different letters are significantly different at $(P \leq 0.05)$

erage was tested and the hulu-mur analogue contains some soluble nitrogen, whereas commercial non-alcoholic carbonated beverage devoid of soluble nitrogen. This finding indicates that the raw materials, mainly Feterita malt, used for the preparation of hulu-mur analogue could have higher nitrogenous compounds, and hence better nutritional quality, than those used in commercial non-alcoholic beverage. The calorific value of hulu-mur analogue and non-alcoholic carbonated beverage were 35.847 and $32.96 \mathrm{kcal} / 100 \mathrm{~mL}$, respectively. The hulu-mur analogue contains higher $(P \leq 0.05)$ calorific value than commercial non-alcoholic carbonated beverage, and thus could be used to counter energy malnutrition in many rural areas in the globe. The results on mineral composition of hulu-mur analogue indicated significant $(P \leq 0.05)$ differences from that of commercial carbonated beverage (Table 5). With exception to $\mathrm{Mg}$, the hulu-mur analogue contains significantly $(P \leq 0.05)$ higher contents of minerals ( $\mathrm{Na}, \mathrm{K}, \mathrm{Ca}$, and $\mathrm{Fe}$ ) compared to commercial non-alcoholic carbonated beverage. This could be resulted from the fermentation and germination processes implemented in the preparation of hulu-mur analogue, as these processes are well known to improve mineral content and extractability of various grains (Nour et al., 2010; Sokrab, Mohamed Ahmed, \& Babiker, 2012). In addition to that, the added spices and condiments could also contribute to the high concentration of these minerals in hulu-mur analogue making it nutritionally and organoleptically sound. Strikingly, higher concentration of these minerals in hulu-mur carbonated beverage indicated the superior nutritional quality of this newly developed drink compared to commercially available non-alcoholic carbonated beverage such as Champion. Among the studied minerals, the level of Fe in hulu-mur analogue is about 4 times higher than its content in commercial non-alcoholic beverage. Thus, the developed carbonated drink could deliver some essential minerals such as iron to children for proper growth and healthy life.

\section{Conclusions}

In this study, an attempt was made to develop a carbonated hulu-mur analogue based on sorghum malt extract. The Feterita variety was found to have a high level of sugars and other chemical constituents and it thus produced good malt. The optimum temperature and time for the kilning of sorghum malt were $150{ }^{\circ} \mathrm{C}$ for $20 \mathrm{~min}-$

IJFS | October 2016 | Volume 5 | pages 120-130 
utes, respectively. Equal portions of spices extracts were found to produce an acceptable Hulumur analogue flavor. Sorghum malt extract to carbonated water ratio of 1.5:1.0 was found to produce the intended carbonated sorghum malt beverage. Generally, hulu-mur analogue carbonated beverage outscores the commercially available non-alcoholic carbonated beverages in terms of organoleptic, physicochemical, and nutritional qualities. Further studies shall specifically focus on the determination of the shelf life of hulu-mur analogue carbonated beverage.

\section{References}

Agab, M. A. (1985). Fermented food products 'Hulu Mur' drink made from Sorghum bicolor. Food Microbiology, 2(2), 147-155. doi:10.1016/S0740-0020(85)80007-1

Agu, R. C. \& Palmer, G. H. (1998). A reassessment of sorghum for lager-beer brewing. Bioresource Technology, 66(3), 253261. doi:10.1016/S0960-8524(98)00047-9

AOAC. (2000). Official methods of analysis of AOAC International (14th ed.), Association of the Official Analytical Chemists Association of official Agricultural Chemists, Washington, USA.

AOAC. (2003). Official methods of analysis of AOAC International (17th ed.), Association of the Official Analytical Chemists, Gaithersburg, MD, USA.

Askar, A. \& Treptow, H. (1993). Quality assurance in tropical fruit processing. Berline; New York : Springer-Verlag. doi:10.1007/ 978-3-642-77687-8

Belton, P. S. \& Taylor, J. R. N. (2004). Sorghum and millets: protein sources for Africa. Trends in Food Science \& Technology, 15(2), 94-98. doi:10.1016/j.tifs.2003.09. 002

Chapman, H. \& Pratt, P. (1982). Methods of analysis of soil, plant and water, 2nd edition. University of California, Agricultural Division Chapman, Riverside, CA, USA.

Chaudhary, N. \& Vyas, S. (2014). Effect of germination on proximate composition and anti nutritional factor of millet (ragi) based pre- mixes. International Journal of Food and Nutritional Sciences, 3(4), 72-77.

Coghe, S., Martens, E., D'Hollander, H., Dirinck, P. J., \& Delvaux, F. R. (2004). Sensory and instrumental flavour analysis of wort brewed with dark specialty malts. Journal of the Institute of Brewing, 110(2), 94-103.

Coghe, S., D'Hollander, H., Verachtert, H., \& Delvaux, F. R. (2005). Impact of dark specialty malts on extract composition and wort fermentation. Journal of the Institute of Brewing, 111(1), 51-60. doi:10.1002/j. 2050-0416.2005.tb00648.x

Dirar, H. A. (1993). The indigenous fermented foods of the Sudan: a study in African food and nutrition. CAB international.

Dwidar, M., Lee, S., \& Mitchell, R. J. (2012). The production of biofuels from carbonated beverages. Applied Energy, 100, 47-51. 11th International Conference on Clean Energy (ICCE), Fen Chia University, Taichung, TAIWAN, NOV 02-05, 2011. doi:10.1016/j.apenergy.2012.02.054

Elbaloula, M. F., Yang, R., Guo, Q., \& Gu, Z. (2014). Major nutrient compositions and functional properties of sorghum flour at 03 days of grain germination. International Journal of Food Sciences and Nutrition, 65(1), 48-52. doi:10.3109/09637486.2013. 836736

Elkhalifa, A. E. O. \& Bernhardt, R. (2013). Some physicochemical properties of flour from germinated sorghum grain. Journal of Food Science and Technology-mysore, 50(1), 186-190. doi:10.1007/s13197-0110315-2

Elmaki, H. B., Babiker, E. E., \& El Tinay, A. H. (1999). Changes in chemical composition, grain malting, starch and tannin contents and protein digestibility during germination of sorghum cultivars. Food Chemistry, 64(3), 331-336. doi:10.1016/S03088146(98)00118-6

El-Faki, A. E. \& Eisa, E. S. (2010). Physicochemical characteristics of some soft drinks of sudan during shelf life. Journal of Science and Technology, 11(2), 57-62.

El-Faki, A. E. \& Eisa, E. S. (2008). Evaluation of hazard analysis and critical control points (haccp) implementation in the soft drinks 
industry (fouz factory) a case study. Gezira Journal of Engineering and Applied Sciences, 3(2).

Hassan, A. B., Ahmed, I. A. M., Osman, N. M., Eltayeb, M. M., Osman, G. A., \& Babiker, E. E. (2006). Effect of processing treatments followed by fermentation on protein content and digestibility of pearl millet (Pennisetum typhoideum) cultivars. Pakistan J Nutr, 5(1), 86-89. doi:10.3923/pjn. 2006.86.89

Hosseini, E., Kadivar, M., \& Shahedi, M. (2012). Physicochemical Properties and Storability of Non-alcoholic Malt Drinks Prepared from Oat and Barley Malts. Journal of Agricultural Science and Technology, $14(1), 173-182$.

Ibnouf, F. (2012). The value of women's indigenous knowledge in food processing and preservation for achieving household food security in rural Sudan. Journal of Food Research, 1(1), 238-253. doi:10.5539/jfr. v1n1p238

IMNA. (2002). Dietary reference intakes for energy, carbohydrate, fiber, fat, fatty acid, cholesterol, protein and amino acids. Washington: The National Academies Press. Retrieved from http://www.nap.edu/read/ 10490/chapter/1

Jairath, S., Sahota, P., \& Pandove, G. (2012). Preparation of Non-Alcoholic Naturally Carbonated Beverage Using Yeast Isolate from Whey Beverage. Czech Journal of Food Sciences, 30(2), 135-143.

Kim, K. O., Kim, M. K., Kang, Y. Y., \& Lee, Y. C. (1993). Effects of malting conditions on quality characteristics of malt and roasted malt extract. Cereal Chemistry, 70(4), 440-442.

Lasekan, O. O., Lasekan, W. O., \& Idowu, M. A. (1997). Flavour volatiles of 'malt beverage' from roasted sorghum. Food Chemistry, 58(4), 341-344. doi:10.1016/S03088146(96)00202-6

Malik, V. S., Schulze, M. B., \& Hu, F. B. (2006). Intake of sugar-sweetened beverages and weight gain: a systematic review. American Journal of Clinical Nutrition, 84(2), 274288.
Mead, B. \& Curnow, R. W. (1983). Statistical methods in agricultural experimental biology, 1st edition. Chapman and Hall, New York, USA.

EL-Mubarak, A., Abdalgadir, M., M.a nd Abdalmagid, \& Mohamed, A. (2005). Diagnostic Studies of Industrial Sector, Food Industry Sector, Annual report, Ministry of Industry, Khartoum, Sudan, (in Arabic).

Mustafa, G. A. (2007). Preparation of carbonated beverage from locally grown tamarind fruit (Aradaib) (Master's thesis, Sudan of Academy of Sciences).

Nour, A. A. M., Ahmed, I. A. M., Babiker, E. E., \& Yagoub, A. E. A. (2010). Investigations on winter season Sudanese sorghum cultivars: effect of sprouting on the nutritional value. International Journal of Food Science and Technology, 45(5), 884-890. doi:10.1111/j.1365-2621.2010.02211.x

Obuzor, G. U. \& Ajaezi, N. E. (2010). Nutritional content of popular malt drinks produced in Nigeria. African Journal of Food Science, 4(9), 585-590.

Okoli, E. V., Okolo, B. N., Moneke, A. N., Ire, F. S., et al. (2010). Effects of cultivar and germination time on amylolytic potential, extract yield and wort fermenting properties of malting sorghum. Asian Journal of Biotechnology, 2(1), 14-26. doi:10.3923/ ajbkr.2010.14.26

Phiarais, B. P. N., Wijngaard, H. H., \& Arendt, E. K. (2005). The impact of kilning on enzymatic activity of buckwheat malt. Journal of the Institute of Brewing, 111(3), 290-298.

Ranganna, S. (2001). Proximate analysis, color measurement and sensory evaluation. In Handbook of analysis and quality control of fruits and vegetable products. (pp. 32150). Tata McGraw Hill Co. Ltd., New Delhi, India.

Sokrab, A. M., Mohamed Ahmed, I. A., \& Babiker, E. E. (2012). Effect of malting and fermentation on antinutrients, and total and extractable minerals of high and low phytate corn genotypes. International Journal of Food Science and Technology, 47(5), 1037-1043. doi:10.1111/j.1365-2621. 2012.02938.x 
Steen, D. (2007). Carbonated beverages. In Chemistry and technology of soft drinks and fruit juices (pp. 150-181). Blackwell Publishing Ltd. doi:10 . $1002 /$ 9780470995822.ch7

Traore, T., Mouquet, C., Icard-Verniere, C., Traore, A. S., \& Treche, S. (2004). Changes in nutrient composition, phytate and cyanide contents and alpha-amylase activity during cereal malting in small production units in Ouagadougou (Burkina Faso). Food Chemistry, 88(1), 105-114. doi:10.1016/j.foodchem.2004.01.032

Ulaiwan, U. (2008). Beer production from Thai rice (Doctoral dissertation, Suranaree University of Technology, Thailand).

Yahya, H., Linforth, R. S. T., \& Cook, D. J. (2014). Flavour generation during commercial barley and malt roasting operations: A time course study. Food Chemistry, 145, 378-387. doi:10.1016/j.foodchem.2013.08. 046 